\title{
Modelling The Influence Of The Drivers Of Supply Chain Performance In The Food Retail Industry In South Africa
}

Chriss Narick Mangoukou Ngouapegne, Vaal University of Technology, South Africa Elizabeth Chinomona, Vaal University of Technology, South Africa

\begin{abstract}
The objective of this research is to examine the antecedents of supply chain value in the food trade business in the Gauteng region of South Africa. This study considers three of these drivers, namely buyer-supplier trust, commitment and supply chain relationship durability. A numerical approach was implemented in which a survey questionnaire was used to collect data from 429 managers and staff members from food retailing firms in the Gauteng province. The study used a non-probability convenience sampling technique to select respondents. Information were analysed through two software packages, namely the Statistical Package for the Social Sciences (SPSS version 24.0) and the Analysis of Moment Structures (AMOS version 24.0). The main goal of this research is to see if the data fits the model. A confirmatory factor analysis was applied in examining and testing the relationships between observed constructs and their causal latent constructs while structural equation modelling helped in testing the hypothesised relationships among variables. The results of the investigation made known that buyer and supplier trust, commitment and supply chain relationship endurance absolutely and meaningfully impact supply chain performance. This investigation concludes that to achieve greater supply chain performance, food retailers should expedite the levels of trust, commitment and length of relationships with their providers. The outcomes of this study offer valuable understandings on how companies in the food retail industry could profit from trust, commitment and relationship longevity along with on how to develop supply chain performance. The results of this study add to the current body of knowledge by generating new information on buyer-supplier relationships. Therefore, the study is useful to buyers and suppliers in the food retail industry who wish to enhance supply chain performance and develop better relationships.
\end{abstract}

Key-words: Buyer-Supplier Trust; Buyer-Supplier Commitment; Supply Chain Relationship Longevity; Supply Chain Performance; Commitment-Trust Theory

\section{INTRODUCTION}

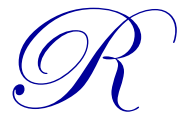

egarding competitive improvement and collaborative standing in supply chain logistics associations, Klein, Rai and Straub (2007), as well as Bischescu and Fry (2009) investigated supply chain performance linked to management. According to Gavrea, Ilies and Stegerean (2011), achieving supply chain performance is the aim of every organisation since it is only because of effectiveness that organisations are capable to develop and progress. Supply chain efficiency is, arguably among all one of greatest constructs in the field of management study and, possibly, the most important indicator of organisational performance. For a firm to achieve increased supply chain performance, it is essential for partners to enhance the association by building trust and commitment. The influence of trust is crucial in the success of the supply chain system. In fact, Ghosh and Fedorowicz (2008) scrutinised the effect of trust in the midst of collaborative, planning, estimating and renewal processes, and found that trust is vital in the execution and improvement of supply chain performance. In addition, Panayides and Venus Lun (2009) specify that trust is of ultimate importance to supply chain partners, meanwhile without it several supply chain systems being practically implemented would not have operated proficiently. In this sense, trust is relevant in supply chain, because it is an essential element to build and maintaining healthy long-standing relationships among partners (Pinto, Slevin \& English, 2009). From the educational perspective, trust, commitment, relationship longevity and supply chain performance were examined against different backgrounds. In this prospect, the current investigation affirmed the degree of influence of these variables as relationship dimensions within the food retail 
sector. This study gives an argument on buyer-supplier relationship practices from a service industry perspective, which is favourable for food retail industry in the Gauteng province in South Africa.

\section{PROBLEM STATEMENT}

Trust is a vital factor in stimulating commitment between associates in the supply chain and the existence of trust upsurges probabilities of supply chain achievement (Aghamohammadi, Bazrafshan, Naeimi \& Rad, 2014). Besides studies by Xiao, Zheng, Pan and Xie (2010) as well as Nyaga, Whipple and Lynch (2010), there is limited evidence of previous research that has examined similar constructs. In addition, limited study has been directed in the field of supply chain management concerning buyer and supplier relationships in South Africa. In the same background, there is a research gap that exists in the relation between buyer and supplier trust, commitment and supply chain relationship longevity and supply chain performance in the food retail sector. Prajogo and Olhager (2012) add that internationally, most studies investigating the relationship between buyers and suppliers have been less than encouraging. This provided evidence that more studies focusing on these constructs were still required in South Africa. Therefore, the aim of this study was to examine the antecedents of supply chain effectiveness in the retail food industry in the Gauteng province.

\section{LITERATURE REVIEW}

\section{The Commitment-Trust Theory}

To obtain suitable contextual and organisational understanding of this study, Morgan and Hunt (1994) theory of commitment-trust is a widely-established framework to scrutinise the influence of trust and commitment on supply chain longevity performance. This theory suggests that the presence of these variables is key to producing outcomes that foster competence, boosting ptoduction and success (Morgan \& Hunt, 1994). A study by Partha (2012) also found out that trust and commitment are crucial elements for increasing longevity relationship in with the intention of achieving supply chain performance. The theory of commitment-trust presupposes that the joined presence of commitment and trust are imperative in relations and reassure firms to maintain relationship investments as well as to emphasis on the benefits of long-term relationships (Palakshappa \& Gordon 2005). A small number of academics suggest that the commitment-trust phenomenon is a worldwide underpinning factor for business relationships (MacMillan, Money \& Downing 2000). The study by Wanga, Wang and Liu (2016) revealed that this theory is comprised of a model named the key intermediating variable. According to Partha (2012:40) this model suggests that "commitment and trust serve as intermediaries between five antecedents, which are relationship termination costs, relationship benefits, shared values, communication and opportunistic behaviour". There are also five outcomes, which include "acquiescence, propensity to leave, cooperation, functional conflict and decision-making uncertainty" (Wanga et al. 2016). Through focusing on the commitment-trust theory of association presentation proposed by Morgan and Hunt, this study intends to apply the theory on formal food retailers and suppliers by showing the direct link between trust and commitment and how these two concepts lead to association durability as well as supply chain performance.

\section{Food Retail Industry}

According to Scott (2015:1), food retailing is extremely important as without retailers people cannot access the products they need daily. Therefore, food retailers are important actors in using resources intelligently, decreasing effects on the atmosphere and humanity, and shaping consumer behaviour (Bekele, Bosona, Nordmark, Gebresenbet, \& Ljungberg 2012:373). This is so, since, they have a good commercial size and tactical plan among the producers and consumers. Furthermore, food retailers are significant for any individual as people buy goods from them every day, which includes all food such as milk, fruit, fish, meat, eggs, bread and several other goods. In addition, food retailers provide fresh vegetables (Suttle, 2016). Besides that, the importance of food retailers can be observed through the role that they play in manufacturing and consumption. In fact, it is apparent that food retailers have a serious part in the renovation of communities and this is obvious through the creation of jobs and a green economy (Evans \& Denney, 2009). For Chkanikova et al. (2013), food retailers influence the choices of consumers with their ability to inform them. In addition, food retailers are trusted by society regarding the management of food. Continuing on the same path, Chkanikova et al. (2013) say that food retailers are the players who are defining and socially organising 
sustainable consumption and this is possible through their ability to translate the demands of consumers for sustainable food into specific approaches. In society, food retailers are the most extensive network, for example, they communicate through the channels of newspapers, magazines, social media, television, radio, internet, word of mouth and shop windows (Evans \& Denney, 2009). The food retailers are significant because they make the food available, affordable, and acceptable for the customer and they have the ability to provide a great quantity and quality of food. They have also settled a variety of health and wellness advantages in the Gauteng province as well as in the whole country (Igumbor et al. 2012).

\section{Buyer-Supplier Trust}

According to Botta-Genoulaz, Campagne, Llerena and Pellegrin (2010), well-known Greek philosophers such as Aristotle, Plato and Socrates concentrated on the concept of trust; they saw it as an abstract phenomenon that played a very important part in the organisation of society for the reason that it includes moral virtues (honesty) and cognitive virtues (reason). Buyer-supplier trust is defined as the firm's (food retailer's) faith that another partner (supplier) will achieve activities that will results in constructive results for the bussiness as well as not take unanticipated movements that will end in undesirable consequences (Stefanie, Philip, Kim \& Helmut, 2010). Trust is one of the most commonly variable studied in current organisational literature (Burke, Sims, Lazzara \& Salas, 2007). Due to that, it has an important influence on the operations of any organisations, therefore, trust influences information sharing, communication, cooperation and it affects productivity (Powell, 2011). Furthermore, the significance of trust in supply chain affairs might be observed in the study of Photis, Panayides and Lun (2009) where the findings propose that trust facilities better understanding and reflect the needs for service in the supply chain more exactly. For Chavhan, Mahajan and Joshi (2012), trust is essential for buyer and supplier to build a relationship. Additionally, Tolmay and BadenhorstWeiss (2015) suggest that for the relationship to be fruitful, trust between the supply chain associates is fundamental, due to that, trust has to be promoted and raised up in order for the relationship or collaboration to exist. In much the same way Wisner, Tan and Leong (2016) add that trust is relevant for any relation or alliance in the workplace. Through trust the parties involved in the relationships are able to keep their promises no matter what happen in terms of providing retailers with the required products (Bracey, 2016). By keeping their promises both parties are on the same level and aid each other in times of problems (Kemunto \& Ngugi, 2014).

\section{Buyer-Supplier Commitment}

Purchaser-provider commitment is seen as an enduring understanding among the formal food retailer and the provider in engaging their capital incomes to improve and develop common benefits (Tungjitjarurn, Suthiwartnarueput \& Pornchaiwiseskul, 2012). Commitment is very important to develop a relation among seller and purchaser; in fact, because of commitment the partners are able to sustain a constant and longstanding relationship in order to realize long-standing benefits (Rahmoun \& Debabi, 2012). Commitment in the relationship helps both providers and purchasers to get common respect, and so it reinforces the social relationship that encourages participative behaviors from both sides (Birasnav, Mittal \& Loughlin, 2015). Buyer-supplier commitment aids to enhance supplier's competences and the information transfer from the purchaser to the provider (Wagner, Coley \& Lindemann, 2011). Moreover, it develops quality and improves the behaviour of the suppliers in order for them to focus on the quality of the products that they offer to their customers (Imran, Sis, Cinar \& Cetin, 2011). Furthermore, commitment is significant in any relationship because it involves the acceptance of a long-term positioning to the relationship, temporary losses in order to achieve long-term benefits (Serem \& Bor, 2015). According to Serem and Bor (2015) the existence of commitment in buyer and supplier relationship reinforce the constancy of relationship; in fact, Carr and Kaynak (2007) support this statement by saying the better the commitment of the supplier to a specific buyer, the better the constancy of that relationship.

\section{Supply Chain Relationship Longevity}

Supply chain relationship longevity or relationship longevity is the commitment of a buyer to a lasting affiliation with a buyer (Flynn, Morita \& Machuca, 2011). Also, supply chain relationship longevity can be defined "as the creation and preservation of specific relationships as durable, though the will for improving particularity on the part of each party could also participe in growing the number of lasting relationships" (Adams, Khoja \& Kauffman, 2012:31). According to Ideet and Wanyoike (2014), the principal element for any industry to be successful is the development 
and maintenance of buyer and supplier relationship longevity. Scholars such as Liu, Li, Tao and Wang (2008) as well as Stanko, Bonner and Calantone (2007) have found that through longevity relationships supply chain members are more closed and their relation is more stable than ever. As long as the relationship is durable the supply chain members are able to maintain it and to work together as a team, this makes the relationships to be stronger than ever before (Makau \& Muturi, 2015) not necessary for mutual economic benefits (Krause, Handfield \& Tyler, 2007) but to achieve the market objectives of the firm performance (Qrunfleh \& Tarafdar, 2014). On the words of Serem and Bor (2015), through long-term relationship the supply chain partners understand each other and they are loyal to each other too. Moreover, being part of supply chain longevity relationships, suppliers help the buyers to fulfil the customer orders successfully and reduce the current stock (Deshpande, 2012). Lees and Nuthall (2015) note that when suppliers are involved in stable relationship longevity they gain more; such as enhancing service delivery, reduced cost, increasing efficiency, continual improvement of operations, along with consolidation of the supply chain (Davies, 2014).

\section{Supply Chain Performance}

In this study, supply chain value is the aptitude of any food retailer to distribute products with good quality and the required quantity at low cost and at the precise time (Zelbst, Green, Baker \& Sower, 2010). Numerous studies have elaborated on the significance of supply chain performance, due to that Choi and $\mathrm{Wu}(2009)$ as well as $\mathrm{Wu}$, $\mathrm{Choi}$ and Rungtusanatham (2010) concluded that supply chain value is significant because it supports supply chain partner's to evaluate their contribution to the firm. It formulates the basis for understanding, the division of common benefits among supply chain partners. Thus, according to Azeem and Ahmed (2015:22) supply chain performance "has the aptitude of improving the image of food retailers and to develop it perfectly because it is the final results of the relationship between the associates". Moreover, supply chain performance is important for partners such as formal food retailers and their suppliers because it allows the collaborators to be more determinante to pursuit the strategic purposes and accomplish joined benefits with the development of their corporation (Xiao et al. 2010). Thus Nyaga et al. (2010:101) presented that "joined benefits, determination and committed investments lead to trust and commitment". Wu, Chou, Shih and Wang, (2011) postulated that trust and commitment, in turn, lead to superior performance in the long run. Moreover, because of such achievement retailers such as formal food retailers have understood that supply chain performance is related to financial performance and to non-financial performance (Fantazy, Kumar \& Kumar, 2010). On one hand, financial performance can be identified as business revenue, incomes per share, sales growth or total shareholder return (Ibrahim \& Ribbers, 2009). While on the other hand, non-financial performances are linked to the quality of the good, those retailers' supplies which satisfy the final customers. Banker and Mashruwala (2007); Ibrahim and Ribbers (2009) described these non-financial performance as leadership, workforce development, on time distribution, improvement, achievement of strategic objectives, market share, effectiveness and output.

\section{CONCEPTUALISED FRAMEWORK AND RESEARCH HYPOTHESES FORMULATION}

This sub-section provides the conceptual framework and discusses the development of hypotheses.

\section{Conceptualised Framework}

Figure 1 illustrates a framework of the constructs and hypothesised relationships investigated in the study. 
Figure 1. Framework of hypothesized relationships

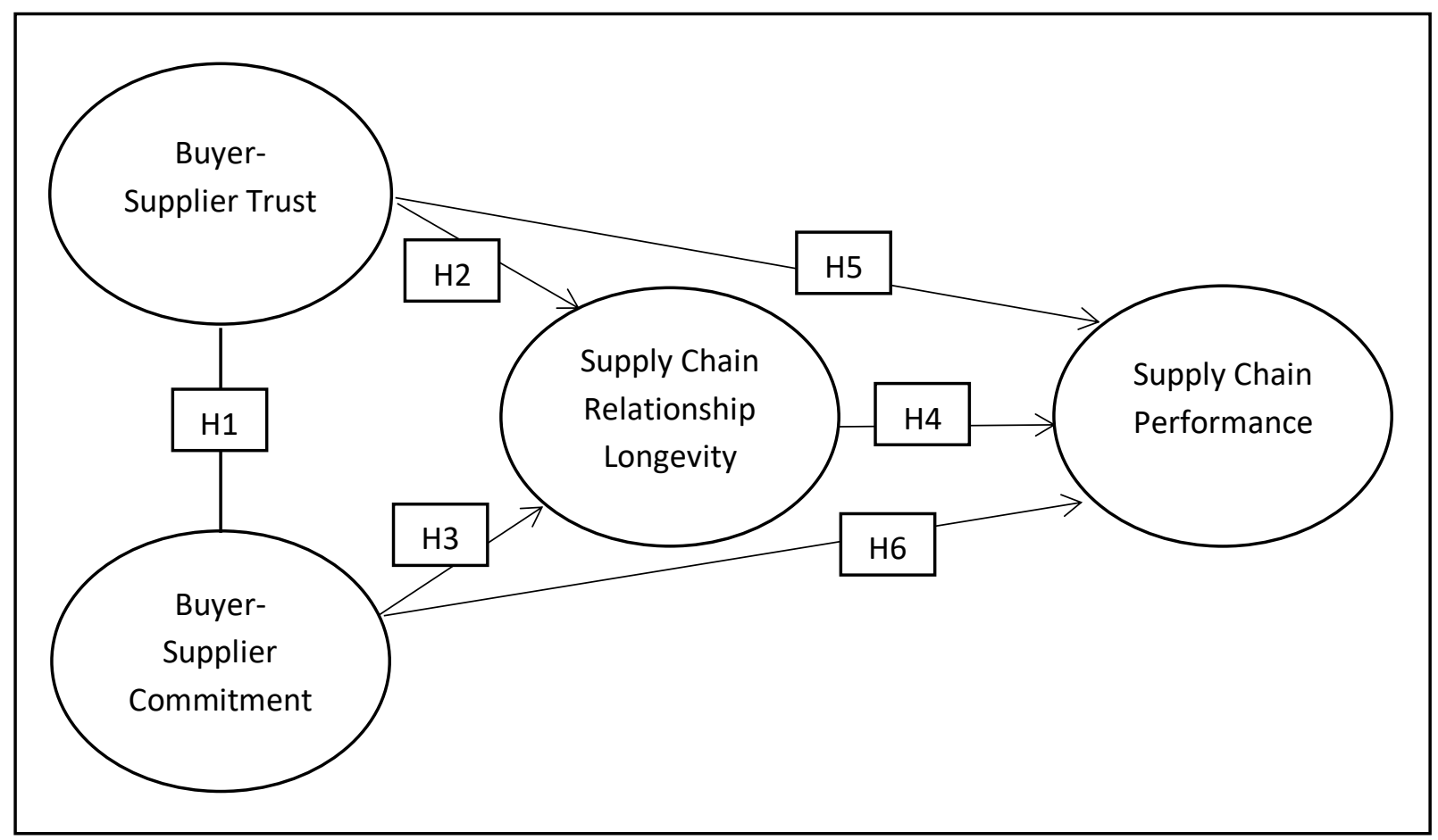

\section{RESEARCH METHODOLOGY}

The current study was based on the positivist paradigm. This was because the positivism paradigm is associated with the quantitative approach due to its scientific, objective and traditionalist characters (Collis \& Hussey, 2014:46); therefore, it has provided statistical proof for every hypothesis made in this study. Moreover, the purpose of this study was to test the relationship between the research variables and the examination of relationships is related to the positivism paradigm. Furthermore, the positivism paradigm was used in this study because it has the advantage of collecting a great amount of data (Raddon, 2012:3). This study intended to use a large sample size, based on that, the adoption of positivism is primordial in the study.

For this study, the target population is the formal food retailers located in the Gauteng province. It was composed of hotels, restaurants, vegetable markets and hypermarkets, such as Woolworths, Checkers, Shoprite, Pick n Pay, Kentucky Fried Chicken and McDonald's. It was not possible to have an exact number of formal food vendors in the Gauteng region due to the lack of a formal list; however, there are more than 400 formal food retailers in the province.

\section{Sample Size}

Sample size refers to how many respondents should be included in the study, and is an important consideration for researchers as it affects the quality and generalisation of the data (Erdis, 2011: 117). In other words, the sample size is the number of respondents included in an investigation. In this study the sample size was set at $n=429$ respondents. Previous researchers such as Karmakar, Islam, Kibria, Hossain and Sattar (2012: 231), Ahmed, Qazi and Perji (2011:12515) and Adesina and Chinonso (2015:4) made use of between 300 and 400 respondents in order to obtain accurate and reliable results for their studies.

\section{Sampling Method}

According to McLeod (2014:1), a sample method is the process of selecting participants from the population. Sampling methods fall into two categories: probability and non-probability samples. This study was focused on non- 
probability sampling, which is defined as samples in which the sampling techniques do not give respondents equal chance of being selected (Malhotra, 2010:376). A convenience sampling technique was applied in this study to collect data from respondents. The convenience sampling technique was chosen because it was quick and cheap, also because respondents were conveniently available (Creswell et al. 2012).

\section{Descriptive Statistics}

In this study 483 questionnaires were distributed, out of this, 429 were retained and 54 questionnaires were unusable because of errors such as uncompleted questions. The respective response rate of the 429 was $89 \%$. Table 1 indicate the gender of the respondents who were involved in this study. The results show that majority of the respondents were males $(57.8 \%$ : $n=248)$ while 42.2 percent $(n=181)$ of those who participated in the survey were female. This distribution by gender shows that there were more males than females in this study. Moreover, in the same table, 429 questionnaires were distributed; all respondents were aged above 16 years old. A large number of them, 41.0 percent $(n=176)$ were aged between 26 and 35. Around 29.4 percent $(n=126)$ of respondents' age was between 36 and 45 years old. About $14.0 \%(\mathrm{n}=60)$ were between $16-25$ years old. Other respondents aged between 46 and 55 years old totalled 10.0 percent $(n=43)$. Only 5.2 percent $(n=24)$ of the respondents were aged above 56 years old. These results imply that those aged between 26 and 35 years were the majority amongst respondents and that those aged above 56 were the minority in the study. In this regard, the second group age is the highest and this implies that the population is more active in improving their labour force in the food retail industry. Furthermore Table 1 indicated that the mainstream of the respondents were black; 62.7 percent $(n=269)$, followed by Indians; 19.1 percent $(n=82)$, White; 13.5 percent $(\mathrm{n}=58)$ and Coloured; 4.7 percent $(\mathrm{n}=20)$.

Table 1. Respondent's demographic characteristics

\begin{tabular}{|c|c|c|}
\hline & Frequency & Percentage \\
\hline \multicolumn{3}{|c|}{ Gender } \\
\hline Male & 248 & $57.2 \%$ \\
\hline Female & 181 & $42.2 \%$ \\
\hline Total & 429 & $100 \%$ \\
\hline \multicolumn{3}{|c|}{ Age } \\
\hline $16-25$ years & 60 & $14.0 \%$ \\
\hline $26-35$ years & 176 & $41.0 \%$ \\
\hline $36-45$ years & 126 & $29.4 \%$ \\
\hline $46-55$ years & 43 & $10.0 \%$ \\
\hline 56 and more & 24 & $5.6 \%$ \\
\hline Total & 429 & $100 \%$ \\
\hline \multicolumn{3}{|c|}{ Race } \\
\hline Black & 269 & $62.7 \%$ \\
\hline White & 58 & $13.5 \%$ \\
\hline Indian & 82 & $19.1 \%$ \\
\hline Coloured & 20 & $4.7 \%$ \\
\hline Total & 429 & $100 \%$ \\
\hline
\end{tabular}

\section{MODEL FIT ASSESSMENT FOR CONFIRMATORY FACTOR ANALYSIS}

In this study, CFA is applied to scrutinise and test that relationships among a set of observed constructs and a set of underlying latent constructs exist. CFA is important in this study because it provides evidence and confirmation that all items are well associated with the correct latent variables within the general construct being measured (Holtzman \& Vezzu, 2011:1651). In the following section, the CFA model fit results are presented.

\section{Model Fit Assessment Index of CFA}

Table 2 outlines the nine goodness of fits criteria as well as the results obtained in this study. The table is followed by the interpretation. 
Table 2. CFA results

\begin{tabular}{l|c}
\hline \multicolumn{1}{c|}{ Fit index } & Results \\
\hline Chi-square ( $\mathrm{x}^{2)}$ & 3.183 \\
\hline Goodness of Fit Index (GFI) & 0.905 \\
\hline Normed Fit Index (NFI) & 0.919 \\
\hline Relative Fit Index (RFI) & 0.903 \\
\hline Incremental Fit Index (IFI) & 0.943 \\
\hline Tucker Lewis index (TLI) & 0.932 \\
\hline Composite Fit Index (CFI) & 0.942 \\
\hline Augmented Goodness of Fit Index (AGFI) & 0.901 \\
\hline Root Mean Square of Error Approximation (RMSEA) & 0.071 \\
\hline
\end{tabular}

Table 2 depicts that the degrees of autonomy of the chi-square are 3.183. This value is above the normal threshold of 3. A chi-square value of 3.183 led to the acceptance of the data (Arbuckle, 2013), this means that a chi-square value of 3.183 in this study is acceptable and fits the model. Furthermore, Table 5.13 shows that GFI (0.905); NFI (0.919); RFI (0.903); IFI (0.943); TLI (0.932); CFI (0.942) and AGFI (0.901) meet the recommended threshold of 0.9 as suggested by Chang, Suki and Tam (2014), which signifies a respectable fit. Finally, RMSEA is 0.071 less than the minimum threshold of 0.08 (Hoe, 2008) as presented in Table 2; this confirms a good model fit. In totality, scrutinising these nine goodness of fit statistics, it can be said that all of them are acceptable because they met the requirements and that the data fits the model accurately.

\section{Structural Equation Modelling (SEM)}

In this study, SEM was used to assess the interactions between the research variables. This procedure covers multiple regression analysis and path model analysis.

\section{Model Fit Assessment of SEM}

Table 3 shows the depth of autonomy of the chi-square point of 2.919. This value is below the recommended threshold 3 (Hinterhuber \& Liozu 2013:93), which therefore suggests an acceptable model fit. Moreover, table 3, indicates a value of 0.899 for GFI (close to the normal standard of 0.9); the adjusted GFI is 0.900 which is equal to the normal standard of 0.9 as provided by Lytras, De Pablos, Ziderman, Roulstone, Maurer and Imber (2010:80). As such, the GFI value of 0.899 is acceptable and fits the model accurately. Furthermore, the following fit indices, NFI (0. 928); RFI (0.911); IFI (0.951); TLI (0.940); CFI (0.951) and AGFI (0.900) are all above the recommended value of 0.9, which means a satisfactory model fit. The value of RMSEA is 0.067 , which is below the required threshold of 0.08 , thus confirming an acceptable fit. In entirety, examining these nine goodness fit statistics, it can be concluded that all of them are acceptable and that the data fits the model.

Table 3. SEM model fit indices results

\begin{tabular}{l|c}
\hline \multicolumn{1}{c}{ Fit index } & Results \\
\hline Chi-square $\left(\mathrm{x}^{2)}\right.$ & 2.919 \\
\hline Goodness of Fit Index (GFI) & 0.899 \\
\hline Normed Fit Index (NFI) & 0.928 \\
\hline Relative Fit Index (RFI) & 0.911 \\
\hline Incremental Fit Index (IFI) & 0.951 \\
\hline Tucker Lewis index (TLI) & 0.940 \\
\hline Composite Fit Index (CFI) & 0.951 \\
\hline Augmented Goodness of Fit Index (AGFI) & 0.900 \\
\hline Root Mean Square of Error Approximation (RMSEA) & 0.067 \\
\hline
\end{tabular}




\section{Hypotheses Testing}

This section discusses the six hypotheses by addressing their validity or acceptance through structural equation modelling.

Table 4. Results path modelling

\begin{tabular}{l|c|c|c|c}
\hline \multicolumn{1}{c}{ Proposed hypothesis relationship } & Hypothesis & $\begin{array}{c}\text { Path coefficient } \\
\text { estimates }\end{array}$ & P-value & Decision \\
\hline Buyer-supplier trust $\rightarrow$ buyer-supplier commitment & H1 & 0.845 & $* * *$ & Accepted \\
\hline Buyer-supplier trust $\rightarrow$ relationship Longevity & H2 & 0.509 & $* * *$ & Accepted \\
\hline Buyer-supplier commitment $\rightarrow$ relationship longevity & H3 & 0.648 & $* * *$ & Accepted \\
\hline Relationship longevity $\rightarrow$ supply chain performance & H4 & 0.808 & $* * *$ & Accepted \\
\hline Buyer-supplier trust $\rightarrow$ supply chain performance & H5 & 0.502 & $* * *$ & Accepted \\
\hline Buyer-supplier commitment $\rightarrow$ Supply chain performance & H6 & 0.479 & $* * *$ & Accepted \\
\hline
\end{tabular}

As presented in Table 4, above and in Figure 2, the levels of the coefficients of all the six hypotheses are substantial at a level of $p<0.01$. For Chinomona, Lin, Wang and Cheng (2010:191), significance levels of $p<0.05, p<0.01$ and $\mathrm{p}<0.01$ are signs of positive, strong and significant relationships between the research constructs. Based on that, all of the six hypotheses proposed in this study were supported and accepted.

Figure 2. Path-Co-Efficiency Results

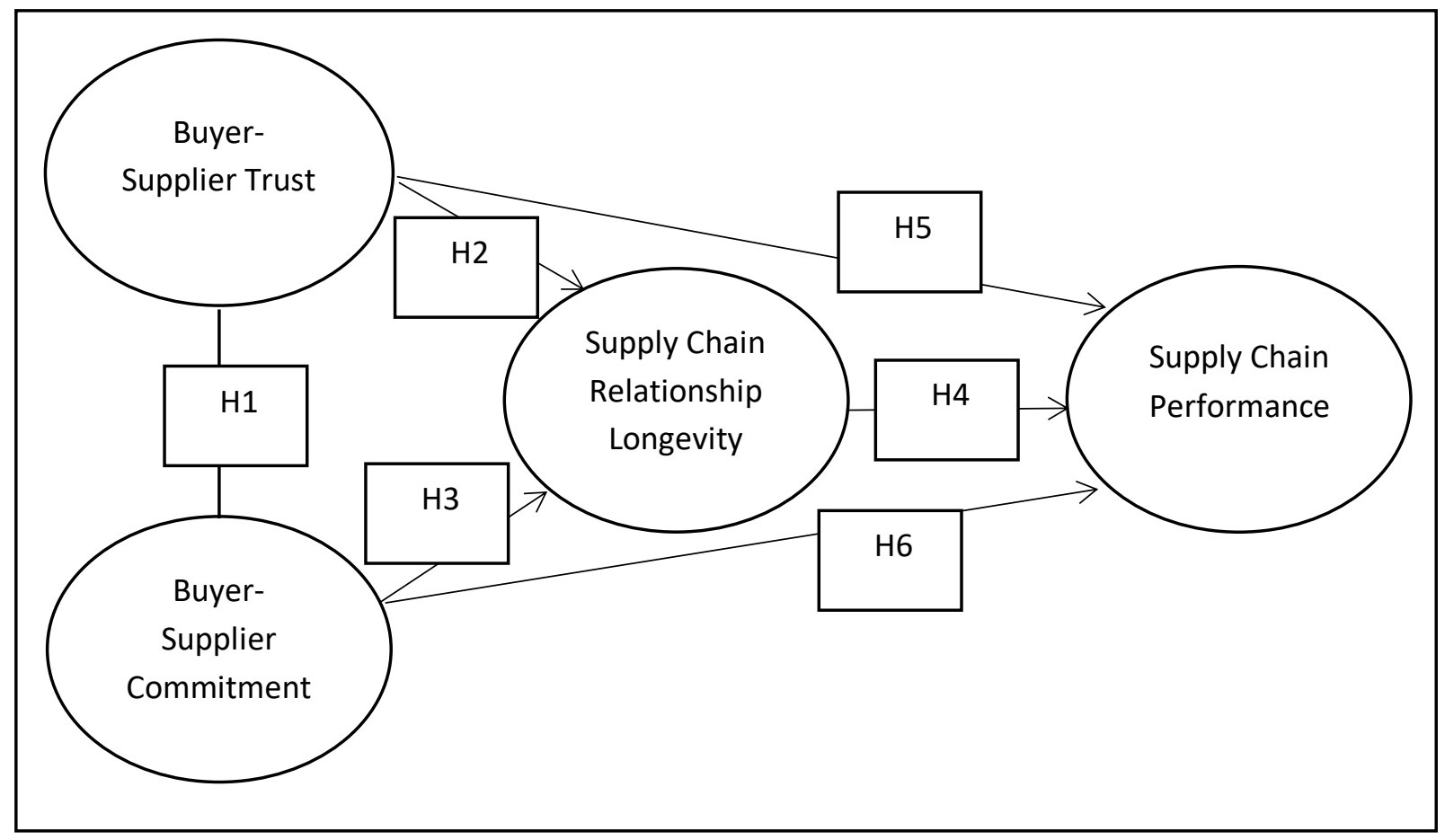

\section{DISCUSSION OF RESULTS}

The results of the hypotheses (from H1 to H6), are significant and supportive at a confidence level of $\mathrm{p}<0.01$. The following section discusses the result of the hypotheses indicated in Table 4 and Figure 2. The first hypothesis (H1) in this study stated that buyer and supplier trust has a substantial impact on buyer-supplier commitment. The 0.845 is the path coefficient of (H1), this value indicates a very strong relationship between buyers and suppliers in the food 
retail industry. Thus, the p-value is significant at $99 \%(\mathrm{r}=0.001)$, which means that this hypothesis is supported and significant. These outcomes are in line with a study done by Mpinganjira, Roberts-Lombard and Svensson (2017), which showed that buyer-supplier trust positively influences buyer-supplier commitment in a business relationship. Additionally, Abdullah and Musa (2014) confirm that buyer-supplier commitment considerably influences buyersupplier trust; the authors go further by saying that the impact of buyer-supplier trust on buyer-supplier commitment is better and more important. Also results of this investigation concur with the results of a study done by Hashim and Tan (2015), concerning the facilitating role of trust and commitment on associates' constant information sharing intention. The authors found that trust is the key factor in developing and increasing commitment for both parties involved in a relationship. Hence, this study confirms that the existence of trust in buyer-supplier relationships influences commitment between the supply chain members. First, trust exerts a constructive influence on commitment because supply chain members have confidence that the other party is reliable and capable of doing what they are predicted to do (Kabadayi, Alan \& Erdebil, 2011). The authors go further by saying that when trust exists between the supply chain partners, they are certain of continuing special investments which will occur with limited risk. Secondly, trust influences commitment because the concept of trust implies that the aims and reasons of the partner are to help when new situations arise (Sezen \& Yllmaz, 2007). Lastly, trust impacts on commitment because it provides confidence that buyers and suppliers will not act opportunistically towards each other (Mpinganjira et al. 2017). This is because no supply chain members will under ordinary conditions want to be committed to an untrustworthy partner.

With reference to the second hypothesis (H2), the study hypothesised that buyer-supplier trust significantly influences relationship longevity. Table 4 indicates a path coefficient value of $(r=0.509)$ with $(p<0.001)$ for H2; the results are significant and confident at $99 \%$. The path coefficient affirms the presence of a reasonable association among buyersupplier trust and relationship longevity. The positive correlation found between buyer-supplier trust and relationship longevity is consistent with the results provided by Mugarura (2010), as well as Ziggers and Henseler (2016). Drawing from a study conducted by Ahimbisibwe, Nangoli and Tusiime (2012), trust is an indispensable precondition for operational relationships between buyer and supplier. From this examination, it can be said that long-time relationship between buyers and suppliers, built on trust has the ability to intensify the performance of the supply chain members and consequently it is advisable to invest in relationship longevity. First, for Barnes, Leonidou, Siu and Leonidou (2010), trust is imperative in relationship longevity because it develops a need to stay and fortify the relation between the supply chain partners. Secondly, in the same sentiment, Dahwa, Al-Hakim and Ng (2013) explain that the significance of buyer-supplier trust to relationship longevity was described by the fact that it is a singularity that improves the asset of intra-organisational relationships and inter-organisational relationships in the food retail industry. Lastly, trust is important in the food retail industry because when the supplier trusts the buyer it is more plausible that the supplier will meet the demands of the buyer (Mukherji \& Francis, 2008). These authors further point out that trust is important in attaining the link of longevity amongst buyers and suppliers because it has the ability to upturn profits for supply chain partners.

A positive correlation was hypothesised between buyer-supplier commitment and relationship longevity. After testing $\mathrm{H} 3$, a path coefficient of $(\mathrm{r}=0.648)$ was obtained. The result confirms that there is a constructive relationship among BSC and RL. The relationship between these two constructs is highly significant at $99 \%$ indicated by a $(\mathrm{p}<0.001)$. The results confirm or validate the existence of the relationship. These outcomes are reliable with the results of Le Tuong and Vo Hong (2014), where commitment was found to be the most significant factor to influence relationship longevity. Moreover, the study of Cambra-Fierro and Polo-Redondo (2011) revealed that commitment influences buyers-suppliers to continue with relationships in the future. This means that once buyers and suppliers are committed to the relationship, the establishment of the association between them will possibly be long-lasting. Therefore, supply chain members are prepared to loss short-term welfare to preserve the relationship. Some researchers and academics have elaborated on the importance of buyer-supplier commitment on relationship longevity. First, this is the case of Teli, Gaikwad, Mundhe and Chanewar (2013), who say that continuous success is achievable when buyers and suppliers are committed to a long-standing relationship. Secondly, for Sarang, Bhasin and Verma (2015), commitment influences relationship longevity because commitment allows the supply chain partners to be involved in a relationship that will upgrade their cost competences, quality, techniques and delivery. Lastly, contending on the impact of commitment on relationship longevity, Chowdhury (2012) suggests that buyers and suppliers have to cultivate commitment for relationship longevity to reach a reasonable benefit in the marketplace. 
The fourth hypothesis (H4) showed that relationship longevity is strongly associated with supply chain performance. The relationship is confirmed through the results of the path coefficient $(\mathrm{r}=0.808)$ and the regression path is highly significant $(\mathrm{P}<0.001)$ at $99 \%$ of confidence. Accordingly, the current study validates and supports that relationship longevity positively influences supply chain performance. The results of this study are constant with the findings of a study directed by Adams et al. (2012), whereby relationship longevity is absolutely linked with supply chain performance. Similarly, the results are congruent with previous studies (Prajogo \& Olhager, 2012; Moshkdanian \& Molahosseini, 2013). In addition to the results of this study, it emerged that buyers and suppliers in the food retail industry are seeking relationship longevity to achieve the firm's performance. This view confirmed a study conducted by Al-Shuaibi (2016). Relationship longevity and supply chain performance combined demonstrate perfect conditions for a firm's success. Relationship longevity is important in the food retail industry because buyers are now able to use fewer providers over an extended period of time (Prajogo \& Olhager, 2012). The authors went further by saying that having a large number of suppliers will make buyers change suppliers often. For Khan, Liang and Shahzad, (2015), relationship longevity affects supply chain performance because it reduces uncertainty and increases information flow between the buyers and suppliers in the food retail industry; as a result, the consumer will receive a better quality product at an effective cost timeously. Lastly, relationship longevity affects the food retailer's performance because it leads to consumers' receptiveness, which will lead to maintaining a strategic collaboration to promote the performance of buyers and suppliers (Zhou, 2011).

The fifth hypothesis (H5) was held and recognised in the current study. To confirm this, there was an affirmative and important correlation $(\mathrm{r}=0.502 ; \mathrm{p}<0.001)$ among consumer-provider trust and supply chain value. This relationship was validated at $99 \%$. These results are constant with previous studies (Nyakundi, 2014; Sung \& Kang, 2013; Ketkar, Kock, Parente \& Verville, 2012). Furthermore, these results support a study conducted by Revilla and Knoppen (2015), by confirming that buyer-supplier trust is completely related to supply chain performance. The results of this study show that it is very important for supply chain partners to develop trust in their relationships in order to achieve supply chain performance. Due to the results of this study, it is important for buyers and supplier to develop long-term relationships in order to attain supply chain performance. This means that relationship longevity between supplier and buyer improves efficiency on supply chain effectiveness. Trust is a key for supply chain performance because it increases the profit of buyers and suppliers in the food retail industry leading to openness and greater knowledge, gratefulness and the creation of value (Sarang et al., 2015). Additionally, in the view of Mao, Lee and Deng (2008), trust influences supply chain value because it leads to fulfilment and upcoming business growth. Moreover, in the view of Hu, Xiao, Xie and Saraf (2011), buyer-supplier trust between partners reduces the chance of opportunistic behaviour from supply chain members; the authors add that trust increases supply chain receptiveness, and improve market performance of the buyers and suppliers in the food trade business. Trust helps purchasers and providers in the food industry to build mutual loyalty and to satisfy their needs (Kosgei, 2016).

With regard to hypothesis (H6), it can be concluded that there is an affirmative relationship amongst purchaser provider commitment and supply chain effectiveness with a positive path number of $(\mathrm{r}=0.478 ; \mathrm{p}<0.001)$ that validates the hypothesis. These results are in agreement with the studies of Ziaullah, Feng and Akhter (2015) and Ashnai, Henneberg, Naudé and Francescucci (2016), who found that commitment strongly impacts supply chain performance. In this study, commitment is one of the key factors to achieving supply chain effectiveness. A relationship associated with commitment between supply chain partners, results in improving the performance of the firm involved in the relationships. Therefore, it is clear that no relationship exists without commitment. For that reason, it is primordial for food retailers to develop it. First, buyer-supplier commitment is vital for the supply chain in the food retail industry because it is related to risk decrease, cost sharing, economies of scale and admission to external markets (Graça, Barry \& Doney, 2016). Secondly, elaborating on this, Wachira (2013) says that commitment is vital for supply chain performance since it strengthens the supplier's participation in the total strategy of the retailers. Thirdly, for Kosgei (2016), commitment allows buyers to get the product that they are paying for from suppliers and they feel valued. Lastly, when commitment exists between supply chain partners, they are able to honour their contractual obligations (Anin, Essuman \& Sarpong, 2016). 


\section{RECOMMENDATIONS}

The following recommendations are proposed for food retailing firms:

\section{Recommendations for Buyer-Supplier Trust}

In order to improve buyer-supplier trust, food retailing firms are encouraged to implement the following recommendations:

- Develop reliable communication: Through communication, supply chain partners will be able to have healthy relationships, in which important information will be shared.

- Ensure transparency through technology. Trust is an imperative factor in developing buyer and retailer relations, and the best way to develop trust is to create transparency.

- Preserve and surpass commitments: The fastest approach to develop trust in any relationship is by keeping commitments.

- Reveal information: If one party does not provide information, the other party will not do so.

- Reduce buyer and supplier opportunistic behaviour.

\section{Recommendations For Buyer-Supplier Commitment}

In order to improve buyer-supplier commitment, food retailing firms are encouraged to implement the following recommendations:

- Respect and consider the needs and ideas of the other party, which clears the ground for supply chain partners to utilise methods, which maximise the welfares of both parties.

- Have an open mind to resolve conflicts and problems in relationships.

- Develop a detailed understanding of the benefits of buyer and supplier commitment in a relationship.

- Give maximum attention to commitment because it leads to long-term relationships. Therefore, they have to enrich it, to achieve competitive advantage, which will lead to enhanced supply chain performance.

- Through commitment, suppliers should be able to keep their promises to the buyers.

- Develop commitment between supply chain partners, which shows that the suppliers are believable and honest.

\section{Recommendations for Supply Chain Relationship Longevity}

In order to improve supply chain relationship longevity, food retailing firms are encouraged to implement the following recommendations:

- To establish relationship longevity with their buyers, suppliers have to deliver quality products and ensure services.

- Knowing the partners; through relationship longevity, supply chain partners know with whom one cannot conduct business.

- Late payment is not acceptable for suppliers; therefore, buyers should always pay on time in order to avoid damaging the relationship.

- Buyers and suppliers should try their best to achieve long-term relationships because it shows how honest and reputable the supply chain partners are.

- Lasting relationships require the suppliers to invest and engage in the association.

- The supply chain associates should maintain the relationship.

- Protect the interests of the other partners. 


\section{Recommendations for Supply Chain Performance}

To improve supply chain effectiveness, food retailing firms are encouraged to implement the following recommendations:

- Buyers and suppliers should agree on common objectives of engagements, so that they can both be satisfied with the results.

- Supply chain partners should involve in common and focused actions toward each other to reinforce their relationship and to achieve common goals.

- Willingness to share profits is achievable through supply chain relationship and a clear understanding of identifiable benefits for both parties.

- It should be required that the longer the relationship, the lower the costs; One of the paramount advantage of supply chain relationship longevity is the cost reductions that occur from day-to-day activities over the duration of the relationship.

- Retailers should work on building trust and commitment in their relationships and suppliers should provide their best so that both can benefit from the profits of a good purchaser and provider relation.

\section{ACADEMIC AND PRACTICAL CONTRIBUTIONS OF THE STUDY}

Current results of this work provide practical and theoretical contributions. The practical contributions of this study are that buyers and suppliers should develop trust, commitment and relationship longevity to achieve supply chain performance. This means, that once trust and commitment have been developed, it can lead to relationship longevity. Furthermore, based on the outcomes acquired in this study, it might be said that when buyers and suppliers in the food retail industry develop trust, commitment and relationship longevity they are more susceptible to remaining in a significant long-term relationship, with the advantage of achieving effectiveness and resourceful supply chain performance. It has been deduced from this study that developing a relationship between consumers and providers is important because of competitive advantage in the marketplace where the supply chain partners operate. Relationship longevity creates a stable environment for food retailers to grow in an active industry. It also reinforces buyer and supplier relationships against competitors.

The results of the study first demonstrated that trust influences commitment, relationship longevity and supply chain performance. Secondly, that commitment influences relationship longevity and supply chain performance. Lastly, relationship longevity influences supply chain performance. These results demonstrate the effectiveness of the concepts to achieving a firm's performance. However, the lack of trust and commitment in their relationship might create a situation of uncertainty, propensity to leave and opportunistic behaviour, thereby a member benefits at the expense of the other. As a result of such an attitude, one partner might leave or stop the transactions. Thus, in such case, the supply chain members will inspect and verify the quality and the quantity of the goods; this action will increase the transaction costs. Therefore, supply chain associates need to comprehend the importance of trust and commitment in their relationship as well as relationship longevity.

Some theoretical contributions have been made to the existing knowledge. The main outcomes of this study support the relationship marketing theory of Morgan and Hunt (1994:22) and reveal the significance of the theory in the supply chain. In fact this study confirms that trust and commitment are the foremost aspects to consumer and trader relations in the case of the food retail industry; which leads to a stable and continuing relationship with the objective of realising a profit. This study highlights the importance of relationship longevity by revealing that supply chain partners may be engaged in a relationship but the absence of longevity will always result in short-term relationships with lower profits. Therefore, it is primordial to know and apprehend the significance of relationship longevity.

Hence, hypothesised relationships and the empirical results in this study supports the theoretical notion of a confident relations between all hypotheses stated in Chapter 1. Moreover, to show the importance of buyer-supplier trust, when looking at the research model (Figure 1.), this study has demonstrated that buyer-supplier trust is connected with all the constructs of this study by providing scientific evidence. Through this evidence, trust is measured as the most important factor to influence supply chain performance, leading to buyer-supplier commitment and developing a great and long-standing relationship between the supply chain members. Also, based on the results obtained, it can be said 
that buyers and suppliers in the food retail industry may be confident of great returns (profits) as long as they develop trust, commitment and longevity in their relationship. The development of these concepts in any kind of industry or business should attract success.

As it has been observed in this study, the results provide further information to the cumulative body of empirical literature within marketing relationship and supply chain management theory by illustrating the prominence of relationship marketing and by facilitating the description of the marketing relationship between buyers and suppliers in the food industry. Thus, this study proposes an additional contribution to existing literature because it amplifies and reinforces current knowledge within the marketing and supply chain field by giving guidance on how to achieve a greater profit between partners. Additionally, a conceptualised model, data collected from a big provincial population and an acceptable model testing methodology were provided to enhance the literature on marketing relationship theory.

\section{LIMITATIONS OF THE STUDY}

This study was restricted only to the food retail industry located in the Gauteng province; other provinces did not form part of this study. Additionally, among the various demographic variables, only gender, race and age were investigated in terms of their influence on purchaser and seller on trust, commitment, relationship longevity and supply chain performance; even though the results were valid and reliable, other variables such as marital status, educational level, and occupation, could also be investigated. In addition, nationality could be further investigated, since cultural differences may be reflected in the affiliation between buyers and suppliers. Furthermore, the response rate of female respondents was also relatively low, which led to difficulty in generalising the results. Thus, the majority of data were generalised to people between 26 to 35 years, which limited the results to adult people while the other age ranges, could contribute to this study. Furthermore, respondents were reluctant to fill in the questionnaire because of the language barrier. In addition, as the sample frame was not defined in this study; it was difficult to ascertain which retailer was part of the food retail industry.

\section{SUGGESTIONS FOR UPCOMING STUDY}

Since this work was merely fixated on trust, commitment and relationship durability in explaining the antecedents of supply chain performance, future researchers should include other constructs such as information sharing, joint problem resolving, cost reduction and better communication among the supply chain partners to achieve supply chain performance. Additionally, it has been confirmed that trust and commitment are key factors to achieve supply chain performance. Both trust and commitment motivate a rational assurance between buyers and suppliers, which simplifies the development of a dynamic relationship. Therefore, future researchers should try to find methods in which buyers and suppliers can intensify the level of trust and commitment in their collaboration. Moreover, the results of this study have shown that to achieve supply chain effectiveness, consumers and sellers have to establish relationship longevity, which is guided by trust and commitment. For any other organisations and partners, who want to improve their performance, they would have to learn how to develop a strong relationship. However, this study focused only on the food retail industry to explain the antecedents of supply chain performance; future academics could outspread the search to additional industries, as well as to other provinces or outside South Africa, because this study was only focused on the Gauteng province. Extending the study to other industries, might help researchers to compare their results with the objective of showing the differences, similarities and the importance of the elements that affect buyersupplier relationships, as well as SCP based on particular industries.

\section{CONCLUSION}

This study investigated the antecedents of supply chain performance in the food trade commerce in the Gauteng region. After testing all the postulated hypotheses, the results of this study confirmed that there is a constructive and substantial link between BSC and BSC; BST and RL; BSC and RL; RL and SCP; BST and SCP; BSC and SCP. The results revealed that buyer-supplier trust has been determined as a vital element in achieving SCP and as a key element in developing relationship longevity in the food retail industry. To achieve supply chain performance, buyers and suppliers located in the Gauteng province have to develop trust, commitment and relationship longevity. Through 
these factors, buyers and suppliers may gain a competitive improvement in the market. This research is also valid for other industries where the operators wish to achieve better supply chain efficacy.

\section{AUTHOR BIOGRAPHIES}

Chriss Narick Mangoukou Ngouapegne. My name is Chriss Narick Mangoukou Ngouapegne and I was worn on the 1st of May, 1987 in Moanda, Gabon. My parents are Pombo Marie Francise and Mangoukou Joseph (died in 2010 from poison). Growing up with my parents was not especially difficult since each of my parents kept me out of their problems and they got along fine at events where both of them were present. I lived with my mom until I went to high school. In high school, I moved in with my grandparents until I got my matric in 2009. I arrived in South Africa in 2010, where I learnt English at ABC International. From there I was accepted to study at Vaal University of Technology where I graduated for National Diploma in 2014, then B-tech in 2015 and Master in 2018 in logistics. My first article was published in 2016, from now I have been writing and continued with my studies. Currently am a PHD student at Vaal University of Technology.

Elizabeth Chinomona. I am Dr Elizabeth Chinomona. I am a married woman with three children. I did my first degree with the University of Zimbabwe and my Masters with National Cheng Kung University in Taiwan. Currently am working as a Senior lecturer at Vaal University of Technology in the Logistics Department, South Africa. Research is my passion as I always learnt a lot from it and also disseminate knowledge to others. My research areas are entrepreneurship, marketing, supply chain, organizational behaviour and human resources management. I have published more than 30 articles in accredited Journals and more than 10 in non-accredited Journals.

\section{REFERENCES}

Abdullah, Z. \& Musa, R. (2014). The Effect of trust and information sharing on relationship commitment in supply chain management. Procedia-Social and Behavioral Sciences, 130, 266-272.

Adams, J.H., Khoja, F.M. \& Kauffman, R. (2012). An empirical study of buyer-supplier relationships within small business organizations. Journal of Small Business Management, 50(1), 20-40.

Adesina, K.I. \& Chinonsi, K. (2015). Service delivery and customer satisfaction in hospitality industry: A study of Divine Hotel Fountain Hotels Limited, Lagos, Nigeria. Journal of Hospitality and Management Tourism, 6(1), 1-7.

Aghamohammadi, R., Bazrafshan, F., NaeimI, M.R. \& Rad, A.E. (2014). Examining trust and commitment in supply chain. Management Research Report, 2(5), 90-97.

Ahimbisibwe, A., Nangoli, S. \& Tusiime, W. (2012). Moderating effect of buyer-supplier trust on the relationship between outsourced formal contracts and supplier delivery performance: an empirical study of public sector. Journal of Business and Social Science, 3(17), 50-71.

Ahmed, I., Qazi, T.F. \& Perji, A.K. (2011). Mobile phone to youngsters: Necessity or addiction. African Journal of Business Management, 5(32), 12512-12519.

Al-Shuaibi, K.M. (2016). Reaping the benefits of long term relationship with suppliers: An evidence from the Saudi chemical industry. International Journal of Business and Management, 11(8), 203-212.

Anin, E.K., Essuman, D. \& Sarpong, K.O. (2016). The Influence of governance mechanism on supply chain performance in developing economies: Insights from Ghana. International Journal of Business and Management, 11(4), 252-264.

Arbuckle, J.L. (2013) IBM SPSS Amos 22 User's Guide. Retrieved from http://www.sussex.ac.uk/its/pdfs/SPSS_Amos_User_Guide_22.pdf.

Ashnai, B., Henneberg, S.C., Naude, P. \& Francescucci, A. (2016). Inter-personal and inter- organizational trust in business relationships: An attitude-behaviour-outcome model. International Marketing Journal, 52, 128-139.

Azeem, K. \& Ahmed, H. (2015). A study on the role of buyer-supplier relationship on organizational performance: perspective of beverage industry. Scholedge International Journal of Management \& Development, 2(5), 21-39.

Banker, R.D. \& Mashruwala, R. (2007). The moderating role of competition in the relationship between nonfinancial measures and future financial performance. Contemporary Accounting Research, 24(3), 763-793.

Barnes, B.R., Leonidou, L.C., Siu, N.Y.M. \& Leonidou, C.N. (2010). Opportunism as the inhibiting trigger for developing long-termoriented western exporter: Hong Kong importer relationships. Journal of International Marketing, 18(2), 35-63.

Bekele, A., Bosona, T., Nordmark, I., Gebresenbet, G. \& Ljungberg, D. (2012). Assessing the sustainability of food retail business: The Case of Konsum Värmland, Sweden. Journal of Service Science and Management, 5, 373-385.

Birasnav, M., Mittal, R. \& Loughlin, S. (2015). Linking leadership behaviours and information exchange to improve supply chain performance: a conceptual model. Global Journal of Flexible Systems Management, 16(2), 205-217.

Bichescu, B.C. \& Fry, M.J. (2009). A numerical analysis of supply chain performance under split decision rights. Omega, 37(2), 358379.

Botta-Genoulaz, V., Campagne, J-P., Llerena, D. \& Pellegrin, C. (2010). Supply Chain Performance: Collaboration, Alignment and Coordination. Great Britain and United States: ISTE Ltd and John Wiley \& Sons, Inc. 
Bracey, L. (2016). The Importance of business reputation. Retrieved from http://www.businessinfocusmagazine.com/2012/10/theimportance-of-business-reputation/

Burke, C.S., Sims, D.E., Lazzara, E.H. \& Salas, E. (2007). Trust in leadership: A multi-level review and integration. The Leadership Quarterly, 18 606-632.

Cambra-Fierro. J.J. \& Polo-Redondo, Y. (2011). Post-satisfaction factors affecting the long term orientation of supply relationships. Journal of Business \& Industrial Marketing, 26(6), 395-406.

Carr, A.S. \& Kaynak, H. (2007). Communication methods, information sharing, supplier development and performance: An empirical study of their relationships. International Journals of Operations and Production Management, 27(3-4), 346-370.

Chang, M.L.D., Suki, N.M. \& Tam, Y.L.A. (2014). Student satisfaction with the service quality of cafeteria: A structural approach. International Journal of Business, Economics and Law, 4(1), 105-111.

Chavhan, R., Mahajan, S.K. \& Joshi. S.P. (2012). Supplier development: Theories and practices. Journal of Mechanical and Civil Engineering, 3(3), 37-51.

Chinomona, R., Lin, J.Y-C., Wang, M.C-H. \& Cheng, J.M-S. (2010). Soft power and desirable relationship outcome: The case of Zimbabwean distribution channels. Journal of African Business, 182, 200.

Chkanikova, O., Klintman, M., Kogg, B., Lehner, M., Mont, O., Nebelius, N. \& Plepys, A. (2013). Sustainability landscape of Swedish food retailers in the European context. Dissertation. An analysis of the state of green business in the South African retail sector. M.Sc. Dissertation. The University of Cape Town.

Choi, T.Y. \& Wu, Z. (2009). Triads in supply networks: theorizing buyer-supplier-supplier Relationships. Journal of Supply Chain Management, 45(1), 8-25.

Chowdhury, P.P. (2012). Antecedents and consequences of trust and commitment in B2B relationship: A review of literature. Indore Management Journal, 4(2), 49-63.

Collis, J. \& Hussey. R. (2014). Business research: A practical guide for undergraduate and postgraduate students. 4th ed. Great Britain: Palgrave Macmillan.

Creswell, J.W., Ebersohn, L., Eloff, I., Ferreira, R., Ivankova, N.V., Jansen, J.D., Nieuwenhuis, J., ... Van De Westhuizen, C. (2012). $11^{\text {th }}$ ed. First steps in research. Van Shaik Publisher: Pretoria.

Dahwa, M.P., Al-Hakim, L. \& Ng, E. (2013). The importance of trust in procurement practices and its impact on business performance: An empirical investigation from the perspective of the buyer-supplier Dyad. Journal of Relationship Marketing, 12(4), 280300.

Davies, J. (2014). The benefits of supplier relationship management. Retrieved from http://www.winman.com/blog/bid/366854/TheBenefits-of-Supplier-Relationship-Management

Deshpande, A. (2012). Supply chain management dimensions, supply chain performance and organizational performance: An integrated framework. International Journal of Business and Management, 7(8), 2-19.

Erdis, C. (2011). Investigating Customer Service in selected Restaurants in the Tshwane area: An exploratory study. (M. Tech. Thesis). University of South Africa.

Evans, W. \& Denney, M. (2009). Best Environmental practices of leading retailers from Everest, T. 2014.Resolving the qualitativequantitative debate in healthcare research. Medical Practice and Reviews, 5(1), 6-15.

Fantazy, K.A., Kumar, V. \& Kumar, U. (2010). Supply management practices and performance in the Canadian hospitality industry. International Journal of Hospitality Management, 29(4), 686-693.

Flynn, B., Morita, M. \& Machuca, J. (2011). Managing global supply chain relationships: Operations, Strategies and Practices. United States of America: Business Science Reference.

Gavrea, C., Ilies, L. \& Stegerean, R. (2011). Determinants of organizational performance: the case of Romania. Management \& Marketing Challenges for the Knowledge Society, 6(2), 285-300.

Ghosh, A. \& Fedorowicz, J. (2008). The role of trust in supply chain governance. Business Process Management Journal, 14(4), 453470 .

Graça, S.S., Barry, J.M. \& Doney, P.M. (2016). B2B commitment building in emerging markets: the case of Brazil, Journal of Personal Selling \& Sales Management, 36(2), 105- 125.

Hashim, K.F. \& Tan, F.B. (2015). The mediating role of trust and commitment on members' continuous knowledge sharing intention: a commitment-trust theory perspective. International Journal of Information Management, 35(2), 145-151.

Hinterhuber, A. \& Liozu, S. (2013). Innovation in pricing: Contemporary theories and best practices. Canada: Routledge.

Hoe, S.L. (2008). Issues and procedures in adopting structural equation modelling technique. Journal of Applied Quantitative Methods, $3(1), 73-83$.

Holtzman, S. \& Vezzu, S. (2011). Confirmatory factor analysis and structural equation modeling on non-cognitive: Assessments using PROCC CALIS. New Jersey: Educational.

Hu, Q., Xiao, J., Xie, K. \& Saraf, N. (2011). Antecedents and consequences of trust in supply chain: The role of nformation technology. In Proceedings of the 19th European Conference on Information Systems (ECIS).

Ibrahim, M. \& Ribbers, P.M. (2009). The impacts of competence-trust and openness-trust on inter-organizational systems. European Journal of Information Systems, 18(3), 223-234.

Ideet, I.L. \& Wanyoike, D. (2014). Role of buyer-supplier relationship on supply chain performance in the energy sector in Kenya: A survey of Kenya power and geothermal development companies. International Journal of Science and Research, 3(10), 24182424.

Igumbor, E.U., Sanders. D., Puoane, T.R., Tsolekile. L., Schwarz, C., Purdy, C., Swart, R., ... Hawkes, C. (2012). Big food the consumer food environment, health, and the policy response in South Africa. PLoS Med, 9(7), 1-7.

Imran, A., Sis, E., Cinar, O. \& Cetin B. (2011). Improving short and long term supplier development plan. Economics and Management, 
$16(1), 647-653$.

Kabadayi, T.E., Alan, A.K. \& Erdebil, A.E. (2011). The factors affecting the level of trust between buyer seller: An example from household appliances sector. Journal of Global Strategic Management, 5(1), 31-39.

Karmakar, P., Islam, M.M., Kibria, G.M., Hossain, S.M, Mohammad \& Sattar, M. (2012). International Current Pharmaceutical Journal, 1(9), 229-234.

Kemunto, D. \& Ngugi, K. (2014). Influence of strategic buyer supplier alliance on procurement performance in private manufacturing organizations: A case of Glaxo Smithkline. European Journal of Business Management, 2(1), 336-341.

Ketkar, S., Kock, N., Parente, R. \& Verville, J. (2012). The impact of individualism on buyer- supplier relationship norms, trust and market performance: An analysis of data from Brazil and the U.S.A. International Business Review, 21, 782-793.

Khan, S.A., Liang, Y. \& Shahzad, S. (2015). The effect of buyer-supplier partnership and information integration on supply chain performance: An experience from Chinese manufacturing industry. International Journal of Supply Chain Management, 4(2), 20-34.

Klein, R., Rai, A. \& Straub, D.W. (2007). Competitive and cooperative positioning in supply chain logistics relationships. Decision Sciences, 38(4), 611-646.

Kosgei, R.C. (2016). Effect of supplier relationship management on organizational performance: A case study of Kenya airways limited. International Academic Journal of Procurement and Supply Chain Management, 2(2), 134-148.

Krause, D.R., Handfield, R.B. \& Tyler, B.B. (2007). The relationship between supplier development, commitment, social capital accumulation and performance improvement. Journal of Operations Management, 25(2), 528-545.

Lees, N.J. \& Nuthall, P. (2015). Case study analysis on supplier commitment to added value agri-food supply chains in New Zealand. Agricultural and Food Economics, 3(4), 1-16.

Le Tuong, L. \& Vo Hong, D. (2014). Factors affecting a long-term relationship between a retailer and a supplier: A case study from Vietnam. International Journal of Economics, Commerce and Management, 2(10), 1-13.

Liu, Y., Li, Y., Tao, L. \& Wang, Y. (2008). Relationship stability, trust and relational risk in marketing channels: Evidence from China. Industrial Marketing Management, 37(4): 432-446.

Lytras, M.D., De Pablos, P.O., Ziderman, A., Roulstone, A., Maurer, H. \& Imber, J.B. (2010). Knowledge management, information systems, e-learning, and sustainability research. Berlin: Springer.

Mcleod, S.A. (2014). Sampling methods. Retrieved from http://www.simplingpsychology.org/Sampling.html

MacMillan, K., Money, K., \& Downing, S. (2000). Successful business relationships. Journal of General Management, $26(1), 69-83$.

Malhotra, N.K. (2010). Marketing research: An Applied Orientation, $6^{\text {th }}$ ed. Pearson Education: United States of America.

Makau, P.M. \& Muturi, W. (2015). Effects of buyer-supplier relationship on procurement performance of selected supermarkets, Kisii, Kenya. The International Journal of Business \& Management, 3(5), 338-345.

Morgan, R.M. \& Hunt, S.D. (1994). The commitment-trust theory of relationship marketing. Journal of Marketing, 58(3), 20-38.

Moshkdanian, F. \& Molahosseini, A. (2013). Impact of supply chain integration on the performance of Bahman group. Interdisciplinary Journal of Contemporary Research in Business, 5(1), 184-192.

Mao, J.Y., Lee, J.N. \& Deng, C.P. (2008). Vendors' perspectives on trust and control in offshore information systems outsourcing, Information \& Management, 45(7), 482-492.

Mpinganjira, M., Roberts-Lombard, M. \& Svensson, G. (2017). Validating the relationship between trust, commitment, economic and non-economic satisfaction in South African buyer-supplier relationships. Journal of Business \& Industrial Marketing, 32(3), 421-431.

Mugarura, J.T. (2010). Buyer-supplier collaboration, adaptation, trust, commitment and relationship continuity of selected private manufacturing firms in Kampala. Retrieved from https://www.mak.ac.ug/documents/Makfiles/theses/Mugarura_Jude.pdf

Mukherji, A. \& Francis, J.G. (2008). Mutual adaptation in buyer-supplier relationships. Journal of Business Research, 61, 154-161.

Nyaga, G.N., Whipple, J.M. \& Lynch, D.F. (2010). Examining supply chain relationships: Do buyer and supplier perspectives on collaborative relationships differ? Journal of Operations Management, 28(2), 101-114.

Nyakundi, I.N. (2014). Influence of buyer-seller relationships on supply chain performance in the banking industry. A case of cooperative bank of Kenya. (Master Thesis). The University of Nairobi.

Partha, C. P. (2012). Antecedents and consequences of trust and commitment. International Management Journal, 4(2), 49.

Palakshappa, N. \& Gordon, M.E. (2005). Trust and commitment in collaborative business relationships involving New Zealand firms. Paper presented at Australia conference business interaction, relationship and networks, 5th-7th December.

Panayides, P.M. \& Venus lun, Y.H. (2009). The impact of trust on innovativeness and supply chain performance. International Journal of Production Economics, 122, 35-46.

Pinto, J.K., Slevin, D.P. \& English, M. (2009). Trust in project: An empirical assessment of owner/contractor relationships. International Journal of Project Management, 27, 638-648.

Photis, M., Panayides, Y.H. \& Lun, V. (2009). The impact of trust on innovativeness and supply chain performance. International Journal of Production and Economics, 122, 35-46.

Powell, C. (2011). Trust is the essence of leadership. Technology to Innovation Management Review, 1-7.

Prajogo, D. \& Olhager, J. (2012). Supply chain integration and performance: The effects of long-term relationships, information technology and sharing, and logistics integration. International Journal Production Economics, 135, 514-522.

Qrunfleh, S. \& Tarafdar, M. (2014). Supply chain information systems strategy: Impact on supply chain performance and firm performance. International Journal of Production Economics, 147, 340-350.

Raddon, A. (2012). Early Stage Research Training: Epistemology \& Ontology in Social Science Research. Generic Skills Training for Research Students. Leicester: University of Leicester.

Rahmoun, M. \& Debabi. (2012). Dependence and commitment: Main determinants of negotiation between suppliers and retailer. 
International Journal of Marketing Study, 4(3), 100-112.

Revilla, E. \& Knoppen, D. (2015). Building knowledge integration in buyer-supplier relationships: The critical role of strategic supply management and trust. International Journal of Operations \& Production Management, 35(10), 1408-1436.

Sarang, J.P., Bhasin, H. V. \& Verma, R. (2015). Identification of factor for development of buyer supplier relationship. Journal of Research in Business and Management, 3(7), 15-19.

Scott, M. (2015). Explain Meaning And Importance of Retailing? What are the functions of retailers? Retrieved from http://education.blurtit.com/1541986/explain-meaning-andimportance-of-retailing-what-are-the-functions-of-retailers

Serem, W. \& Bor, J. (2015). Effect of buyer-suppliers relationships on buying firm competitiveness in medium and large scale hotels and restaurants in Nakuru municipality. European Journal of Business and Management, 7(4), 280-290.

Sezen, B. \& Yilmaz, C. (2007). Relative effects of dependence and trust on flexibility, information exchange, and solidarity in marketing channels. Journal of Business and Industrial Marketing, 22(1), 41-51.

Stanko, M.A., Bonner, J.M. \& Calantone, R.J. (2007). Building commitment in buyer-seller relationships: A tie strength perspective. Industrial Marketing Management, 36(8), 1094-1103.

Stefanie, L., Philip, Y., Kim, W. \& Helmut, K. (2010). Relational governance mediates the effect of formalconstructs on BPO performance. A paper presented at the 18th European conference on information systems (ECIS). June 8th to 9th, Pretoria, South Africa. Retrieved from http://aisel.aisnet.org/cgi/viewcontent.cgi?article=1121\&context=ecis 2010

Sung, S. \& Kang, S. (2014). Effects of trust determinants on firm performance in the buyer supplier relationships: Empirical evidence from the warehousing firms in Busan, South Korea, 667-685.

Suttle, R. (2016). What Is the Meaning of Retail Food? Retrieved from http://smallbusiness.chron.com/meaning-retail-food-17255.html.

Teli, S.N., Gaikwad, L., Mundhe, P. \& Chanewar, N. (2013). Impact of certification program on supplier selection to reduce quality cost. The International Journal of Engineering and Science, 2(1), 97-102.

Tolmay, A.S. \& Badenhorst-Weiss, J.A. (2015). Supply chain relationships between first and second tier suppliers in South African automotive supply chains: A focus on trust. Journal of Transport and Supply Chain Management, 9(1), 1-8.

Tungjitjarurn, W., Suthiwartnarueput, K. \& PornchaiwiseskuL, P. (2012). The impact of supplier development on supplier performance: the role of buyer supplier commitment, Thailand. European Journal of Business and Management, 4(16), 183-194.

Wachira, R.W. (2013). Supplier relationship management and supply chain performance in alcoholic beverage industry in Kenya. University of Nairobi Digital Repository.

Wagner, S.M., Coley, L.S. \& Lindemann, E. (2011). Effects of suppliers' reputation on the future of buyer-supplier relationships: the mediating roles of outcome fairness and trust. Journal of Supply Chain Management, 47(2), 29-48.

Wanga, W-T., Wang, Y-S. \& Liu, E-R. (2016). The stickiness intention of group-buying websites: The integration of the commitmenttrust theory and e-commerce success model. Information \& Management, 53, 625-642.

Wisner, J.L., Tan, K-C. \& Leong, G.K. (2016). Principles of supply chain management: A balanced approach, Cengage Learning: Boston.

Wu, M-Y., Chou, H-P., Shih, Y-Y. \& Wang, J-H. (2011). Supply chain performance improvement through partner relationship management in the high tech industry. International Journal of Management Science and Engineering Management, 6(3): 210-218.

Wu, Z., Choi, T.Y. \& Rungtusanatham, M.J. (2010). Supplier-supplier relationships in buyer-supplier-supplier triads: Implications for supplier performance. Journal of Operations Management, 28(2), 115-123.

Xiao, X., Zheng, X., Pan, W. \& Xie, X. (2010). Trust, relationship commitment and cooperative performance: Supply chain management. Chinese Management Studies, 4(3), 231-243.

Ziggers, G.W. \& Henseler, J. (2016). The reinforcing effect of a firm's customer orientation and supply-base orientation on performance. Industrial Marketing Management 52,18-26.

Zelbst, P.J., Green, K.W., Baker, G. \& Sower, V.E. (2010). RFID utilization and information share impact supply chain performance. The Journal of Business and Industrial Marketing, 25(8), 582-589.

Zhou, Q. (2011). Applied economics, business and development. Springer: China.

Ziaullah, M., Feng, Y. \& Akhter, S.N. (2015). The synergistic and complementary effects of supply chain justice and integration practices on supply chain performance: A conceptual framework and research propositions. South African Journal of Economic and Management Sciences, 18(4), 519-533. 


\section{APPENDIX 1: QUESTIONNAIRE}

\section{Vaal University of Technology}

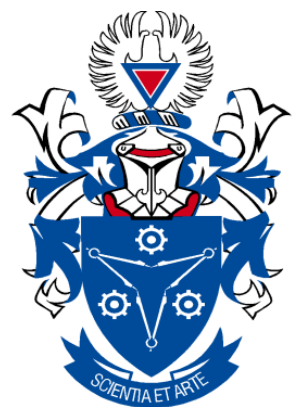

\section{Questionnaire:}

Modelling the influence of the Drivers of Supply Chain Performance in the Food Retail Industry in South Africa

Thank you for paying attention to this academic questionnaire. The purpose of this questionnaire is to gather information on the drivers of supply chain performance in the food retail industry in the Gauteng province. I am therefore, requesting your assistance in completing the questionnaire. The research is purely for academic purposes and the information will be kept confidential. It will take you approximately 10 minutes to complete the whole questionnaire

\section{SECTION A}

\section{Demographic Information}

This section seeks some background information about you. Please indicate your answer by ticking $(\checkmark)$ on the appropriate block.

A1: Please indicate your gender

\begin{tabular}{|l|l|}
\hline Male & \\
\hline Female & \\
\hline
\end{tabular}

A2: Please indicate your age

\begin{tabular}{|l|l|}
\hline $16-25$ & \\
\hline $26-35$ & \\
\hline $36-45$ & \\
\hline $46-55$ & \\
\hline 55 and more & \\
\hline
\end{tabular}

A3: Please indicate your race

\begin{tabular}{|l|l|}
\hline Black & \\
\hline White & \\
\hline Indian & \\
\hline Coloured & \\
\hline
\end{tabular}




\section{SECTION B: BUYER-SUPPLIER TRUST}

Below are statements about buyer-supplier trust. Please kindly indicate the extent to which you agree or disagree with the statement by ticking the corresponding number in the 5-point scale below.

\begin{tabular}{|c|c|c|c|c|}
\hline $\mathbf{1}$ & $\mathbf{2}$ & $\mathbf{3}$ & $\mathbf{4}$ & $\mathbf{5}$ \\
\hline Strongly disagree & Disagree & Moderately agree & Agree & Strongly agree \\
\hline
\end{tabular}

Please tick only one number for each statement

\begin{tabular}{|l|l|l|l|l|l|l|l|l|}
\hline BST1 & $\begin{array}{l}\text { Our suppliers have often provided us with } \\
\text { information that has later proven to be true. }\end{array}$ & $\begin{array}{l}\text { Strongly } \\
\text { disagree }\end{array}$ & 1 & 2 & 3 & 4 & 5 & $\begin{array}{l}\text { Strongly } \\
\text { agree }\end{array}$ \\
\hline BST2 & Our suppliers keep their promises. & $\begin{array}{l}\text { Strongly } \\
\text { disagree }\end{array}$ & 1 & 2 & 3 & 4 & 5 & $\begin{array}{l}\text { Strongly } \\
\text { agree }\end{array}$ \\
\hline BST3 & $\begin{array}{l}\text { Though situations change, we believe that our } \\
\text { partners will be ready and willing to offer us } \\
\text { assistance and support. }\end{array}$ & $\begin{array}{l}\text { Strongly } \\
\text { disagree }\end{array}$ & 1 & 2 & 3 & 4 & 5 & $\begin{array}{l}\text { Strongly } \\
\text { agree }\end{array}$ \\
\hline BST4 & $\begin{array}{l}\text { Whenever our suppliers give us advice on our } \\
\text { business operations, we know that they are } \\
\text { sharing their best judgement. }\end{array}$ & $\begin{array}{l}\text { Strongly } \\
\text { disagree }\end{array}$ & 1 & 2 & 3 & 4 & 5 & $\begin{array}{l}\text { Strongly } \\
\text { agree }\end{array}$ \\
\hline BST5 & $\begin{array}{l}\text { When making important decisions, our suppliers } \\
\text { are concerned about our welfare. }\end{array}$ & $\begin{array}{l}\text { Strongly } \\
\text { disagree }\end{array}$ & 1 & 2 & 3 & 4 & 5 & $\begin{array}{l}\text { Strongly } \\
\text { agree }\end{array}$ \\
\hline
\end{tabular}

\section{SECTION C: BUYER-SUPPLIER COMMITMENT}

Below are statements about buyer-supplier commitment. Please kindly indicate the extent to which you agree or disagree with the statement by ticking the appropriate number below.

\begin{tabular}{|c|c|c|c|c|}
\hline $\mathbf{1}$ & $\mathbf{2}$ & $\mathbf{3}$ & $\mathbf{4}$ & $\mathbf{5}$ \\
\hline Strongly disagree & Disagree & Moderately agree & Agree & Strongly agree \\
\hline
\end{tabular}

Tick only one number for each statement.

\begin{tabular}{|l|l|l|l|l|l|l|l|l|}
\hline BSC1 & $\begin{array}{l}\text { Our company intends to do business with current } \\
\text { suppliers well into the future. }\end{array}$ & $\begin{array}{l}\text { Strongly } \\
\text { disagree }\end{array}$ & 1 & 2 & 3 & 4 & 5 & $\begin{array}{l}\text { Strongly } \\
\text { agree }\end{array}$ \\
\hline BSC2 & $\begin{array}{l}\text { Our positive feelings towards our suppliers are a } \\
\text { major reason we continue working with them. }\end{array}$ & $\begin{array}{l}\text { Strongly } \\
\text { disagree }\end{array}$ & 1 & 2 & 3 & 4 & 5 & $\begin{array}{l}\text { Strongly } \\
\text { agree }\end{array}$ \\
\hline BSC3 & $\begin{array}{l}\text { We have chosen our current suppliers for useful } \\
\text { reasons. }\end{array}$ & $\begin{array}{l}\text { Strongly } \\
\text { disagree }\end{array}$ & 1 & 2 & 3 & 4 & 5 & $\begin{array}{l}\text { Strongly } \\
\text { agree }\end{array}$ \\
\hline BSC4 & $\begin{array}{l}\text { We are willing to put in more effort and } \\
\text { investment in building our business in relation to } \\
\text { our suppliers. }\end{array}$ & $\begin{array}{l}\text { Strongly } \\
\text { disagree }\end{array}$ & 1 & 2 & 3 & 4 & 5 & $\begin{array}{l}\text { Strongly } \\
\text { agree }\end{array}$ \\
\hline BSC5 & $\begin{array}{l}\text { We want to maintain a long-term relationship } \\
\text { with our suppliers. }\end{array}$ & $\begin{array}{l}\text { Strongly } \\
\text { disagree }\end{array}$ & 1 & 2 & 3 & 4 & 5 & $\begin{array}{l}\text { Strongly } \\
\text { agree }\end{array}$ \\
\hline
\end{tabular}




\section{SECTION D: RELATIONSHIP LONGEVITY}

Below are statements about relationship longevity. Please kindly indicate the extent to which you agree or disagree with the statement by ticking the appropriate number below.

\begin{tabular}{|c|c|c|c|c|}
\hline $\mathbf{1}$ & $\mathbf{2}$ & $\mathbf{3}$ & $\mathbf{4}$ & $\mathbf{5}$ \\
\hline Strongly disagree & Disagree & Moderately agree & Agree & Strongly agree \\
\hline
\end{tabular}

Please tick only one number for each statement

\begin{tabular}{|l|l|l|l|l|l|l|l|l|}
\hline RL1 & $\begin{array}{l}\text { Our company expects its relationship with key } \\
\text { suppliers to last a long time. }\end{array}$ & $\begin{array}{l}\text { Strongly } \\
\text { disagree }\end{array}$ & 1 & 2 & 3 & 4 & 5 & $\begin{array}{l}\text { Strongly } \\
\text { agree }\end{array}$ \\
\hline RL2 & $\begin{array}{l}\text { The suppliers see our relationship as a long-term } \\
\text { alliance. }\end{array}$ & $\begin{array}{l}\text { Strongly } \\
\text { disagree }\end{array}$ & 1 & 2 & 3 & 4 & 5 & $\begin{array}{l}\text { Strongly } \\
\text { agree }\end{array}$ \\
\hline RL3 & $\begin{array}{l}\text { We view our suppliers as an extension of our } \\
\text { firm. }\end{array}$ & $\begin{array}{l}\text { Strongly } \\
\text { disagree }\end{array}$ & 1 & 2 & 3 & 4 & 5 & $\begin{array}{l}\text { Strongly } \\
\text { agree }\end{array}$ \\
\hline RL4 & We give a fair share of profits to key suppliers. & $\begin{array}{l}\text { Strongly } \\
\text { disagree }\end{array}$ & 1 & 2 & 3 & 4 & 5 & $\begin{array}{l}\text { Strongly } \\
\text { agree }\end{array}$ \\
\hline RL5 & $\begin{array}{l}\text { We work with key suppliers to improve their } \\
\text { quality in the long run. }\end{array}$ & $\begin{array}{l}\text { Strongly } \\
\text { disagree }\end{array}$ & 1 & 2 & 3 & 4 & 5 & $\begin{array}{l}\text { Strongly } \\
\text { agree }\end{array}$ \\
\hline
\end{tabular}

\section{SECTION E: SUPPLY CHAIN PERFORMANCE}

Below are statements about supply chain performance. Please kindly indicate the extent to which you agree or disagree with the statement by ticking the appropriate number below.

\begin{tabular}{|c|c|c|c|c|}
\hline $\mathbf{1}$ & $\mathbf{2}$ & $\mathbf{3}$ & $\mathbf{4}$ & $\mathbf{5}$ \\
\hline Strongly disagree & Disagree & Moderately agree & Agree & Strongly agree \\
\hline
\end{tabular}

\section{Please tick only one number for each statement}

\begin{tabular}{|l|l|l|l|l|l|l|l|l|}
\hline SCP1 & $\begin{array}{l}\text { Our supply chain has been able to reduce delivery } \\
\text { time to the final customer. }\end{array}$ & $\begin{array}{l}\text { Strongly } \\
\text { disagree }\end{array}$ & 1 & 2 & 3 & 4 & 5 & $\begin{array}{l}\text { Strongly } \\
\text { agree }\end{array}$ \\
\hline SCP2 & $\begin{array}{l}\text { Our supply chain is able to handle non-standard } \\
\text { orders. }\end{array}$ & $\begin{array}{l}\text { Strongly } \\
\text { disagree }\end{array}$ & 1 & 2 & 3 & 4 & 5 & $\begin{array}{l}\text { Strongly } \\
\text { agree }\end{array}$ \\
\hline SCP3 & $\begin{array}{l}\text { Our supply chain is able to produce and offer a } \\
\text { variety of products. }\end{array}$ & $\begin{array}{l}\text { Strongly } \\
\text { disagree }\end{array}$ & 1 & 2 & 3 & 4 & 5 & $\begin{array}{l}\text { Strongly } \\
\text { agree }\end{array}$ \\
\hline SCP4 & $\begin{array}{l}\text { Our supply chain is flexible enough to respond to } \\
\text { changes in customer demand. }\end{array}$ & $\begin{array}{l}\text { Strongly } \\
\text { disagree }\end{array}$ & 1 & 2 & 3 & 4 & 5 & $\begin{array}{l}\text { Strongly } \\
\text { agree }\end{array}$ \\
\hline SCP5 & $\begin{array}{l}\text { Our supply chain is able to handle rapid } \\
\text { introduction of new products. }\end{array}$ & $\begin{array}{l}\text { Strongly } \\
\text { disagree }\end{array}$ & 1 & 2 & 3 & 4 & 5 & $\begin{array}{l}\text { Strongly } \\
\text { agree }\end{array}$ \\
\hline SCP6 & $\begin{array}{l}\text { Our supply chain is able to meet special } \\
\text { specification requirements from customers }\end{array}$ & $\begin{array}{l}\text { Strongly } \\
\text { disagree }\end{array}$ & 1 & 2 & 3 & 4 & 5 & $\begin{array}{l}\text { Strongly } \\
\text { agree }\end{array}$ \\
\hline
\end{tabular}

Thank you very much for taking the time to complete this questionnaire! 